\title{
Living up to Our Students' Expectations - Using Student Voice to Influence the Way Academics Think about Their Undergraduates Learning and Their Own Teaching
}

\author{
C. Yvette Wharton ${ }^{1}$, Lorna J. Goodwin ${ }^{2} \&$ Andrea J. Cameron ${ }^{1}$ \\ ${ }^{1}$ Abertay University, Dundee, UK \\ ${ }^{2}$ St. Mary's University, Twickenham, UK \\ Correspondence: C. Yvette Wharton, Division of Sport \& Exercise Sciences, Abertay University, Bell Street, \\ Dundee. DH1 1HG UK. E-mail: y.wharton@abertay.ac.uk
}

Received: August 19, 2014

Accepted: September 15, 2014

Online Published: September 18, 2014

doi:10.5430/ijhe.v3n4p72

URL: http://dx.doi.org/10.5430/ijhe.v3n4p72

\begin{abstract}
Understanding the student learning experience is essential if Higher Education Institutions (HEI) are to provide an education for the $21^{\text {st }}$ century. This study investigated students' perspectives on their learning experiences and offered undergraduates a chance to influence the way academics think about learning and teaching.

Participants were drawn from two UK HEIs and a semi structured focus group approach was adopted. A total of nine focus groups consisting of 3-7 participants were drawn from across all Sport degree year groups in both institutions. Assessment, pedagogy and teacher characteristics emerged as primary concerns across both institutions. Assessment was appreciated by all students as key to their learning but was exposed as being overly traditional and rigid in its application. Students were unanimous in their support for small group pedagogies, rejecting traditional powerpoint dominated lecturing styles. The emphasis on the behaviour of, and delivery by, tutors was noteworthy.

Students appraised the development of their academic skills and confidence, linking these to motivation, knowledge, self-awareness and critical reflection. In doing so they understood the impact of inconsistencies in tutors' teaching practices. The onus is on every tutor to combine imaginative assessment with dynamic and relational experiences in order to provide a strong foundation for flexible, reflective and creative graduates.
\end{abstract}

Keywords: Assessment, Feedback, Pedagogy, Motivation

\section{Introduction}

From the perspective of education professionals we would contend that the experience of students in the $21^{\text {st }}$ century can be limited where HE institutions fail to review and adapt. The last decade has been characterised by rising numbers and an increasingly diverse student population. In our HEI contexts there are increasing numbers of first generation students as well as adults returning to education through widening access opportunities. Hence, many students self-finance their fees, accommodation and subsistence throughout their studies, creating an environment in which they have to combine regular and term time employment with academia (National Union of Students, 2008). Providing an educational experience that challenges and meets the [value for money] expectations of both student body and the academy should be inherent in programme development and delivery.

Employability and thus extrinsic motivations are core to the educational expectations of this generation of students. This signals a significant change in outlook from more traditional and intrinsic motivational factors, where university education was once regarded more as a vehicle for learning than principally as a route to employment. Upon graduation, students now expect to be equipped with the knowledge and skills to quickly establish themselves in the employment market. Our experience would suggest that many academics still depend on traditional models of teaching and assessment in a formal student: tutor relationship that no longer engages with the aspirations of many of our learners. In order to meet the changing needs of this diverse learning community we believe that education providers should understand the student perspective and that this can best be undertaken by listening to the student voice. 


\subsection{Aims / objectives}

The main aims of the study were to investigate students' perspectives of their Higher Education learning experiences; understand the commonalties experienced by students enrolled on Bachelor degree programmes in the academic discipline of sport education and exercise science; and to utilise the students' voice to challenge for change, giving those most closely involved a chance to influence the way academics think about students' learning and their own teaching.

\section{Literature Review}

The ubiquitous course evaluation, widespread in higher education, authenticates the Higher Education Academy's focus on innovative pedagogy as a workstream. Research to understand students' perceptions of the varied differing learning environments they are exposed to (Burke, Jones \& Doherty, 2005) reflect the vagaries of flexible pedagogy highlighted by Barnett (2014). Yet the learning environment is key to developing the knowledge and skills required by today's graduate. Academics face many challenges in developing environments that will motivate diverse student groups in terms of ability, individual motivation and background. The environment that an academic constructs and directs is a major factor in determining how students engage and develop as independent learners. If students are to be equipped to be graduates in the $21^{\text {st }}$ Century then it is necessary to develop learning environments that enhance their capacity for independent thinking (Hativa \& Birenmaum, 2000) and where they are able to demonstrate higher order skills of analysis, critique and synthesis (Burke et al., 2005).

Through flexible pedagogies students should be challenged and encouraged to demonstrate autonomy in their learning. Effective teaching and assessment, as Railton and Watson (2005) argue, is central to developing that autonomy. It has been suggested when students have responsibility for their own learning that there is a greater probability of developing autonomy, (Van Den Hurk, 2011). However, there may be a danger that academics could expect students to function as autonomous learners from the onset of their studies with little or no explicit structure being put in place to support this (Railton \& Watson, 2005). In addition, it could be argued, although exposed to many teaching and learning methods students may not fully understand either the purpose of an activity or their role in it (Hativa \& Birenbaum 2000). Thereby suggesting that this needs to be more clearly communicated to students (Burke et al., 2005; Railton \& Watson, 2005).

Nonetheless, the design of the curriculum, (Morss \& Murray, 2005), pedagogy and assessments are driven predominantly by approaches that teaching staff believe will address learning objectives, their own preferred teaching styles and beliefs about what encourages students to engage. Jones (2009) argues that there are often inconsistencies present in teaching, with a divergence between the desired aspirations relating to the development of generic skills and actual teaching practices. A key driver in higher education related research is more often the perspective of the lecturers rather than that of the students (Kane, Sandretto \& Heath, 2002).

Most students during their degree programme will be exposed to diverse approaches to teaching and assessment. However, there will also be nuances within these approaches that, for a student, distinguishes specific classes as being more valuable or engaging. The approach to and expectation of individual staff will also differentiate classes. Although modules and degree programme may have defined skills objectives, the diversity of delivery may mean this is, at times, left to chance. In addition the pedagogical approach utilised will have a marked effect on engagement. Hativa and Birenbaum (2000) suggest that students have strong preferences for the type of teaching they wish to be exposed to, reflecting an individual's preferred learning style. The range of approaches to teaching and the breadth of student attitudes to learning, in addition to other demands, can place the student in the position of having to be selective about how and thus what they learn.

It has been suggested that the ability to develop independent learning skills is hampered by large class sizes and time pressures, with academics mitigating pressures by not teaching essential elements (Jones, 2009). In addition, the increased amount of time students now spend engaged in employment, means they are more likely to be strategic in their approach to study (McInnis, 2001). The increase in students from diverse backgrounds and with varied abilities suggests it would be useful to understand how they respond to a range of teaching and learning methods and environments (Van Den Hurk, 2011). Invariably, course evaluations do not provide the in-depth research that explores students' perceptions of the purpose of the differing learning environments they are exposed to (Burke et al., 2005). Unanswered questions include what factors in the learning environment do students consider the most important? Hativa and Birenbaum (2000) also challenge researchers to consider whether students appreciate the differing methods they are exposed to and whether they are able to identify the teaching characteristics most important to their own learning? Similarly, students' conception of learning and their perceptions of the incorporation of varying teaching methods and styles are an enduring feature of higher education research (Buckley, Pitt, Norton \& 
Owens, 2010). If approaches to teaching are to result in high quality learning then it is necessary to understand the changing landscape of both student intentions and strategies and how they understand the learning environment to which they are exposed (Byrne, Flood \& Willis, 2002).

\section{Methodology}

The epistemological framework embraced social constructionism, understanding the student experience as a collective phenomenon shaping knowledge of what it is to study at higher education. Within this way of knowing, a phenomenological approach was utilised as it allowed for the examination of the learning environment from the perspective of students' common and shared experiences. This approach facilitated a deeper understanding about the features of the learning environment (Creswell, 2007); this not only enabled the identification of student perceptions but also allowed the underlying reasons for student responses to be examined. To focus attention on gathering data that led to textural description two key overarching questions were used:

What have you experienced in terms of the learning environment?

What aspects of the learning environment have had most influence or affected your own learning?

To develop this focus and encourage discussion sub questions and themes were explored

What strategies employed encourage and maintains your interest?

What aspects of teaching do you believe encourages your own independent learning?

What tasks promote confidence in your learning?

What are the features of student and learning contexts which influence your responses to teaching situations (Istroff and del Soldato, 1998)?

What tasks give you confidence in your ability to learn?

What approaches to teaching encourage you to want to learn?

What types of assessment promote your engagement and interest?

Are you aware of the responsibility to participate (Van Den Hurke, 2011)?

Do they understand what this means and why it is important?

\subsection{Participants}

Participants represented two higher education institutions, one in England and one in Scotland. Both institutions offer Bachelor degree sport and exercise science programmes and it is from these courses that the focus groups were recruited. Purposeful sampling was used, with participants being drawn from comparable programmes at the two institutions. The need to choose a clearly defined group (or individual) supported the use of purposive sampling for each focus group (Gobo, 2004). Students were approached at the end of lectures when the study and its requirements were explained to them. Volunteers were then allocated to focus groups according to their level of study.

\subsection{Ethics}

Ethics permissions were secured from both institutions. Informed consent was at the heart of the process with students understanding that participation was voluntary and that they could withdraw from the research at any time (British Educational Research Association, 2004).

\subsection{Procedure}

A focus group method was selected to encourage interaction and cooperation (Seale, 2010), thus shared experiences form the basis of discussion. The comfort of exchanging ideas with peers helped reduce the 'Hawthorne effect' of interviews with a course tutor (Angrosino \& Mays de Pérez, 2003). Data was produced as an outcome of these dialogues and new understanding constructed around the phenomenological topic under review.

In both institutions, the focus groups consisted of groups of participants, representing approximately 10 percent of the sport degree student population at that time. The focus group sessions were conducted in a classroom within each University setting. Focus groups were established in each year of study; three years for the English institution and four years for the Scottish institution. The inclusion of a group from each year allowed for comparisons to be made between the different experiences across the stages of study and reflected the changing learning environment. All three researchers undertook focus group research. Reliability was established through cross institution monitoring whereby the content, ethics and sampling frameworks were shared and examined through regular discussion between researchers. The overall schedule for each focus group was based upon key overarching questions and thematic 
probing. While the researchers were aware that individual researcher's idiosyncrasies might have influenced outcomes, this was mediated by the use of generic open questions agreed in advance, and by the joint data analysis undertaken. Validity is more tenuous in interpretive research (Ritchie \& Lewis, 2012) and reflected our concerns that the data appropriately represent the subject matter. Nevertheless, Ladkin suggests interpretivist researchers consider the "usefulness" of the data when considering the validity of interpretivist methods (2004, p. 539). Thus, credibility for this approach, initially established through recognising agreed concepts from literature, sought validity through the joint construction of open questions; demonstrating consistency and relevance through overlapping interpretations of the topic. To further enhance this, a constant comparative method was employed, (Silverman, 2000). All focus groups were voice recorded using a digital Dictaphone.

\subsection{Data Analysis}

The digital recordings were transcribed verbatim and full transcriptions shared between researchers for coherent and in depth analysis (Poland, 2002). Constant checking and comparison of interpretation occurred between researchers to ensure consistency of analysis (Silverman, 2000). Initial review of transcripts allowed primary themes to be generated, initially by each of the research team; this was then augmented through collaborative ideation. Subordinate themes then evolved from the transcription data and overarching concerns were established through further joint interrogation of the data (Gilham, 2000). Textural description was codified by identifying significant themes (table 1). Content analysis (Gilham, 2000) allowed structural description to be identified by examining the context or setting that may have influenced students' experiences of the learning environment (Moustakas, 1994). Data reflected the perspectives of the participants, generating understanding of the learning environment they have experienced. As a consequence this research was concerned with the meanings the students' themselves attributed to the interactions they had experienced (Marshall \& Rossman, 1999).

The resonance between institutions signposted in the data emboldened the research team to posit that our (tutors') perception of student engagement in the learning experience cannot be assumed from the predispositions of academics.

\section{Discussion and Analysis}

Three primary themes emerged from the data. As table 1 indicates, these were assessment, pedagogy and teacher characteristics. These primary themes form a substantive part of the discussion thus engaging the reader with students' key concerns in their learning experience. Concurrent to these primary themes are a number of subordinate themes that transversed the primary themes, underpinning their learning experiences and securing for students an all-embracing context of leaning; academic skills and confidence (table 1).

Table 1. Model of learning concerns for sports' students

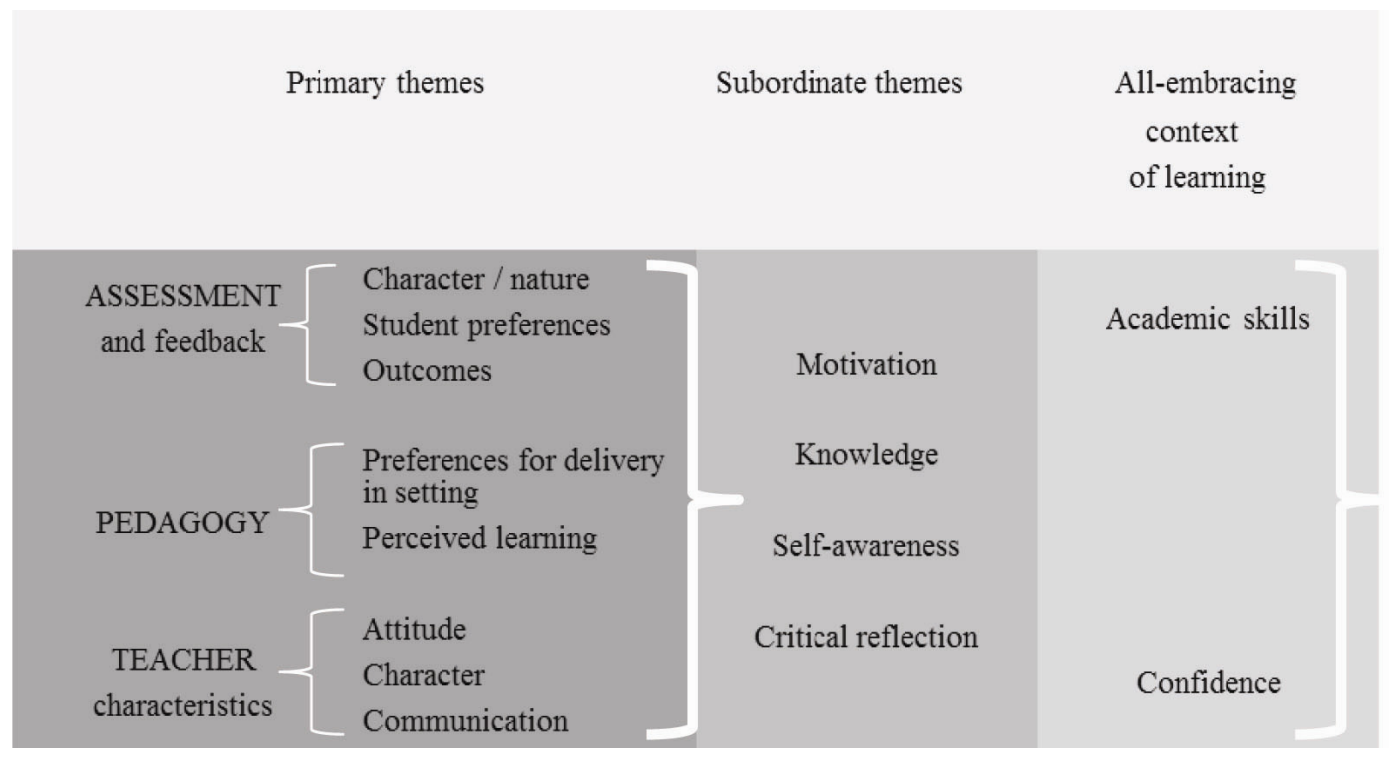




\subsection{Assessment and Feedback}

Assessment is a key component of, and integral to the learning environment, both in terms of the type of assessment and its timing (Quality Assurance Agency, 2011). Students repeatedly highlighted assessment as the key driver for motivating them to learn. This echoes earlier investigations of student learning, which revealed how assessment, rather than teaching dominated students' perceptions (Habeshaw, Gibbs \& Habeshaw, 1993). The students at all stages study tended to identify their preferred mode of assessment when recognising factors they believed helped them learn. The selection of assessment and the perceived associated workload impacts on the learning experience and the learning approach a student will adopt (Stuyven, Dochy \& Janssens, 2005; Gibbs \& Simpson, 2004). However, it has been suggested that assessment can be largely ineffective in supporting appropriate types of learning (Gibbs \& Simpson, 2004). Boud (2007) posits that students as the learners are passive subjects, and that the rules and procedures of assessments dominate. However, Bain (2010) raises the question as to whether or not assessment should act as a means of support that enables the student to take greater responsibility for their own learning and enhance critical thinking. How assessments are designed has the potential to provide a framework that will impact positively on learning; often the studying required to fulfil a task may be more important than the final product (Gibbs \& Simpson, 2004).

Present data elicited varying student responses regarding the worth of different assessments and their perceived demands. There was a universal dislike of exams although the use of multiple choice exams produced diverse results. Students did not believe they performed as well in exams as in other forms of assessment and they thought modules with exams produced poorer grade outcomes. This data, corroborating the earlier work of Yorke, Bridge and Woolf, (2000) and Bridges et al., (2002), should be a concern given that over the past decade higher education has, according to Barnett (2014) sought a more flexible route to assessment for undergraduates. Students noted that the type of assessment has an impact on final grades, with exams resulting in lower module grades when compared to coursework. In addition our data reinforced the argument that multiple choice question exams can result in a surface approach of learning (Scouler, 1998) or rote memorisation (Snyder, 1971) which reflects the comment of one student who suggested that:

“.(MCQs)......they're pointless; perhaps pointless is the wrong word. I think answers where you have to write more than one word gives a better indication of your knowledge"

Third year student

Reasons for disliking exams included difficulty in retaining sufficient information to adequately answer two or three essays in a short time period. They frequently referred to actual practical demands of the exams, such as, remembering sufficient information, ability to write legibly and the time limited nature of the assessment. They also compared the demands and expectations of exams to other assessments suggesting that they remembered more when doing essays compared to exams; with essays they had more time to reflect and did more reading, which was easier to integrate into their work.

\section{“.......there's a lot of information to take in and I think it's impractical to think that} someone can hold the amount of information in their heads for four essay questions"

Third year student

Since current data is also indicative of research showing that coursework is preferred and believed to be fairer than exams, allowing a greater range of abilities to be assessed (Kniveton, 1996) the programme should embrace such student inspired opportunities to challenge and change assessments. There is also evidence to suggest that coursework grades are better at predicting longer term learning (Conway et al., 1992).

As in previous research respondents identified employability and future career prospects and aspirations as key motivators and reasons for pursuing a university education (Kandiko, 2013; Jenkins Breen, Lindsay \& Brew, 2003). Consequently, assessment was considered as a way of demonstrating depth of knowledge and showing prowess. One of the main positive things highlighted about assessment was the possible future transference of the skills used or developed by the assessment. This was most evident when referring to practical or applied assessments:

"The practical side of things, like I found the interview very good as it's quite practical and its relevant to what I want to do" 
Practical assessments and presentations were viewed as promoting and encouraging interaction and were the preferred means of both learning and assessment. Students were also able to reflect on how assessments impacted on overall approaches to learning. These types of assessments increased confidence in their own ability to process information and transfer their knowledge to others. In future employment, it was acknowledged that they would be expected to be competent in a diverse range of skills:

"I think the different ways of assessment we've got make you a flexible learner, so if you're good at essay writing or sit down exams or someone else who is good at practicals, you get tested in all forms. I think that's quite good. In the real world you are not going to be doing the same thing every day. So I think flexible."

Third year student

Presentations were seen as a means of developing both skills and confidence. One fourth year described how presentations had developed his ability to convey relevant information in an appropriate manner and this had informed his own research approach; prioritising and preparing information for slides for his own use and for the understanding of his audience. Again there was a recognition and acknowledgment that the skills of effective presenting were transferrable skills. There was also some acknowledgement that assessments can help redress skill shortfall. A number of fourth years identified how having to do essays developed their abilities to search and sift information to construct an argument in an ordered and coherent way.

Lack of information about assessment criteria was raised as a concern. The students did not expect to be given minute detail but they did want a brief that directed them appropriately and gave them an indication of what the lecturer expected. It has been strongly argued that the role of assessment is to provide focus and clarity regarding expectations (Penny \& Grover, 1996). Thus the amount and quality of information given by individual lecturers was viewed by the current students as either supporting or hindering assessment approaches and was considered fundamental in how they directed their work and effort.

How students responded to their assessment grades was varied, with some highlighting the importance of every grade whilst others seeing the worth only when they influenced degree classification. Those that highlighted the importance of every grade tended to view them as a way of checking their skill development and their knowledge in addition to increasing or maintaining that all-embracing and fundamental confidence (table 1):

“..... despite what people say that they don't count until you are in fourth year, they still

count to me. ....it means I understand what I'm talking about, then it gives you more confidence to keep doing what I'm doing"

Third year student

Emphasis was often placed on passing the assessment rather than achieving a high grade, however, they also noted that they got 'a buzz' when good grades where achieved and this acted as a measure of personal development and motivation (table 1). For some this was only seen in the later years of study when grades became a real concern. In the preceding stages grades were not seen as irrelevant but something to be endured as 'a learning phase' prior to the real work of the later years when degree classification came into play.

"I wouldn't say it didn't bother us.............. felt more anxious about waiting for my

fourth year results than I did in first and second year. Because the grades determine my final degree, so I'm striving to get my best this year; it means a lot more"

Fourth year student

With assessment feedback there was considerable variation in how individuals viewed this, especially with regards to collecting and utilising it. Work by Hattie (1987) suggests that the single most influencing factor on student achievement is feedback. Related to this is the proposition that accurate and specific feedback that relates closely to the task has the capacity to enhance self-efficacy (Linnenbrink \& Pentrich, 2003). In common with previous research (Hounsell, 1987; Wotjas, 1998), for many students in the present study there was a tendency to disregard, not read or even collect feedback. Although this pattern varied between years of study those in the earlier years were more likely to follow this pattern. Some seemed not to recognise the worth of feedback or to appear to be interested in anything other than the grade:

"I just forget if I'm honest. Once coursework is done I kinda move on"

Third year student 
If early feedback is not received then the student may have moved onto the next task and the feedback becomes irrelevant; grades without feedback could be considered damaging (Gibbs \& Simpson, 2004). Irrespective of the quality of the feedback there was a tendency to pick up feedback only if there was a further assessment in the same module. Multiple stage assignments with early feedback can improve the quality of subsequent assessments (Cooper, 2000) and be an incentive to collecting feedback. Students portrayed this as 'learning from your mistakes'. They did not necessarily understand what the assessor was looking for when awarding the grade or, as with previous research, how feedback would help with making improvements in future work (NUS, 2008).

It is evident from the comments that students regard assessment as their main means of learning. In common with previous research (Kandiko \& Mawer, 2013; Jenkins et al., 2003) it is apparent that enhancing employability, acquiring skills and improving self-efficacy and confidence are key stimuli in student approaches and understanding of assessments. It was positive to observe how students were able to reflect on assessment. There was little evidence that suggested a focus merely on achieving a grade as an endpoint. Instead the students demonstrated the ability to highlight some challenges, but also the capacity to link assessment to a personal developmental (self-awareness) process. This process equipped them with knowledge and skills for the future; an ability to self-monitor and helped create flexible adaptive learners. Perhaps the challenge to academics is to look at how assessment supports students to learn, and to examine the functions that assessments perform (Gibbs \& Simpson, 2004). Assessment has the potential to direct and improve/enhance student learning (Bain, 2010) and altering assessment practice could be a driver for change in teaching and learning

\subsection{Pedagogy}

The debate regarding the appropriateness of pedagogy as an adult learner construct compared to an andragogical model, which embraces adult learner abilities and desires, was considered as benefitting our understanding of higher education learners (Reischmann, 2004). Nevertheless, in the light of emerging data we remain engaged with traditional pedagogical patterns (Hiemstra \& Sisco, 1990), that is, teacher-centred instructional approaches that are conventionally didactic and knowledge driven. Thus, our research approach appreciates pedagogy as conceived through students' perceptions of how tutors orchestrate student learning experiences and the subsequent response of learners.

Emerging data determined an appreciation of the overt pedagogical style adopted by tutors. Traditional, rather didactic models of pedagogy have evolved from 'chalk and talk' to 'death by powerpoint' and in sharing their dissatisfaction with such pedagogical modes it is pleasing to confirm the academic intent of our university students. Richardson's (2003) disquiet that the student experience focussed more on reproductive learning than authentic knowledge and understanding still has some justification. This being recognised by student respondents from all learning groups as a poor quality experience:

\section{I've been in some lectures where I can be sitting there and have no idea what the lecturer is going on about, just because of their style, just how they put things across}

Year 4 student

Ning and Downing (2012) make reference to curriculum design, workload, assessment and teaching quality, all characteristics that emerged from our own data regarding tutor perceptiveness, suggesting the need to effect change in response to student needs. Thus, building self-awareness and confidence (table 1) are pivotal to the experience of students in the earlier stages of study. This is redolent of Barnett's (2014) discussion regarding the twelve forms of institutional pedagogical flexibility; advising against didactic adherence to structures not seen as enabling environments for students advancing through their degree studies.

Pedagogical aspirations developed as students matured, with students in the earlier years tending to be somewhat superficial in their learning needs. How students are engaged in deep approaches to learning (Ning \& Downing, 2012) is built upon policy and learning frameworks throughout the HEI experience (Dutton, Hunter \& Broad, 2012), although taking account of student inclination and types of engagement should be the professional concern of academics. Our students not only reflected on the delivery from tutors but upon the personal relationships through interaction within and beyond lectures. Thus students appreciated:

Empathy, we had one lecturer last year, who could see that it was all new and overwhelming for you and put themselves in our shoes.

Year 3 student 
These relational aspects of pedagogical practices held great resonance for students in the early stages of study from both institutions. The most engaging lectures were those which held elements of fun, team or group work. Light-hearted student-tutor relationships acknowledged that the social process of learning episodes initially superseded the development of more self-aware motivation (table 1).

Social processes can impact on learning approaches (Economic \& Social Research Council/Teaching and Learning Research Programme (ESRC/TLRP), 2009), and in the present study held greater significance for less academically confident students:

we are all confident with each other. but if you get put in another group like everyone's quiet and they don't speak out loud and... everything.. especially when we have those massive lectures as well..er .. no one really wanted to speak out loud they felt out of their comfort zone

Year 1 student

Tutors as 'experts' dispensing knowledge were not well received and students felt lost and lacked confidence in such contexts:

A couple of lecturers just stand there and just speak for an age and don't make it interesting and then it's quite soul destroying.

Year 2 student

Such learning preferences are reflective of student motivation - a key feature in discussions regarding effective learning in higher education (table 1). However, students also recognise that not all aspects of a module will be delivered through their preferred learning style, rather that:

$$
\begin{aligned}
& \text { knowing about the strengths and weaknesses of a certain teaching } \\
& \text { method ............ it could be positive in one sense but then one person might be } \\
& \text { excluded due to the style.... However this one might be more } \\
& \text { beneficial ............................... and be somebody else's approach favoured to them }
\end{aligned}
$$

Year 2 student

In recognising that our students' assigned great importance to the personal and social mores of module delivery, the generation of the learning environments has increasing significance for academics. Our students' expectations have resonance with Hocking's (2009) expectation that tutors facilitate a learning experience that is both pleasurable and effective.

\subsection{Motivation}

Reviewing the impact of different pedagogical approaches on the student experience is intricately entwined with students' motivation, self-awareness, confidence and critical reflection (table 1). Motivation to learn embraces both social relationships and the construction of self and self-esteem (Beard, Clegg \& Smith, 2007), emphasising the transformative nature of engagement rather than transmission approaches to learning. Indeed students appreciate and respond to tutors taking a personal interest in the issues affecting them. Students in all year groups were confident in their understanding that acquiring knowledge and applying learning have a symbiotic relationship:

I think it's up to the students to; students are here for a purpose, you've chosen to be here so you have to be pro-active as well. It's kinda interactive rather than just staff's responsibility. You have to work together for it to work

Year 3 student

I know participation has always been important (laughs) although I think some have chosen to participate for the sake of talking. But I think to have a good discussion to get things going ... you have to be aware to get involved in class, if you have people sitting quietly it's not going to be a good discussion.

Year 4 student

Pollard et al. (2008) view such critical reflection from students as a developing academic and cognitive skill, but one that is also inherent in their own personal motivations. While the first years looked forward to developing critical self-awareness, their mindfulness of the importance of such skills and even that such skills exist reinforces self-awareness as a noteworthy aspect of the student learning experience (table 1). 
The concept of perceived learning is inherent in both the construct of self-awareness and in our understanding of motivation and, aptly, developing responsibility for their own learning is acknowledged by student respondents at all levels of study as a personal and academic goal:

I think you can always develop your skills while you are at uni ... but to some extent you need the drive to actually do that.... Because... you're not necessarily going to be handed each opportunity on a plate, you may have to go out and seek them yourself, so you would need to drive to be able to do that

Year 2 student

Fundamental to the student's learning experience is how they perceive events in relation to their own motivation. If we accept the proposition of Remedios and Lieberman (2008), that the diversity of motivation theories essentially converge into intrinsic and extrinsic motivation, we can question whether students believe they enjoy the course more if they are intrinsically/extrinsically motivated. Do they endorse the course and their learning experience because they enjoy the experience itself or are they critical of modules because they did not receive an expected grade? Significantly, for our research, Remedios and Lieberman (2008) consider that it is not incongruous for students to experience both motivational forces in wanting to both understand and achieve.

The complexity of motivational forces are exacerbated by respondents from both institutions positing that the real motivation to succeed was inherent in their disposition upon arrival at university and that without this success was limited.

....I think it's like the motivation to get to where you want I think it was from secondary school I think it was being inspired there and from going to college

Year 2 student

This seems to correspond with Railton and Watson's (2005) assertion that students are expected to adjust to the complex learning environment of university and have the skills to allow them to function as autonomous learners. Our data reinforces the notion that able students expect to perform well academically regardless of situational constraints. Similarly, as the year 4 student noted below, their motivation towards success seemingly occurred naturally without specific effort:

I think the motivation is there a lot of time anyway, there's the interest in the topic, and obviously the end goal of achieving your degree, I don't think I've had to do anything specifically to keep myself motivated.

Through induction, mentoring and academic support approaches much is made of a sense of belonging (Thomas, 2012), however there is a need for further consideration of (self) motivation as an aspect of academic resilience. Notwithstanding Thomas' (2012) concerns of the challenge of translating knowledge regarding success at university to action, student opinions place emphasis upon factors academics should view with some disquiet -students who do not arrive with this motivational disposition.

The model (table 1) authenticates students becoming self-directed, developing their wealth of experience with a prepared-ness to learn through a problem centred approach that is internally motivated. Indeed where the learning experience was less than successful, respondents apportioned blame to peers' own motivation rather than the quality of the learning experience.

Well the people I know who have dropped out have dropped out because they were not getting the grades. But then it's also been because they haven't been trying.

Year 3 student

If we concur with the tenets of Hativa and Birenmaum (2000), in expecting tutors to motivate students, data suggests reassessing the nature of that support towards (self) motivation. In contrast to the implications of the student narrative, Thomas (2012) argues that entry to university should be the starting point rather than a completion point. The ability to self-motivate and be self-reliant were recurrent themes for our participants. This provides the impetus for approaches that recognise students do not enter university with the resilience and self-motivation to deal with the pressures of higher education study. This will not be a new message to tutors but what is interesting is the attitude of the participants across institutions and year groups to those students who do not appear to have such resilience. 


\section{Conclusion}

The opinions of the students were legitimised by the consistency of ideas and responses across all four years of study and both universities. Students can be empowered by research focused on their voice if it is listened to. It is, therefore, incumbent upon those charged with delivering the learning experience to question current practice and instigate fundamental change if merited.

From a social constructionist perspective it is not surprising that students placed considerable emphasis on assessment. Despite many traditional modes of assessment, students were able to identify and reflect on the developmental nature of assessments as part of the whole learning experience. Indeed, a significant majority of the participants felt that accomplishing assessment tasks considerably enhanced their self-confidence. The most engaged students recognised and were able to articulate how these experiences progressively developed their skills and knowledge. They acknowledged that these competencies and attributes would be essential for effective assimilation into the work place, which reflected the extrinsic motivation many felt was key to success. Nevertheless, understanding assessment as an on-going learning process that influences and is influenced by the learner activity invites the tutor and student to re-engage with the accepted practice of a limiting model of summative assessment.

Students were unanimous in their support for individualised and small group pedagogical approaches. Their subjective norms enabled the belief that they have the skills and capacity to be effective learners in such settings. All participants experienced negative feelings and a diminished desire to engage with peers and tutors in large groups contexts. They also understood the significance of building self-confidence in 'safe' learning environments. Fear of public embarrassment and a resistance to risk taking outside familiar small group contexts reinforced these concerns. The students considered settings that required active and applied learning to be best practice, thus further rejecting traditional powerpoint dominated lecturing approaches.

The motivational forces influencing students' experiences and commitment embrace both an individual's established sense of purpose and the personal attributes required to ensure favourable outcomes and the intrinsic motivation to learn. Indeed, their observations acknowledged that those most likely to be successful learners were those already equipped with the intrinsic self-motivation to read, engage and pursue knowledge.

The emphasis placed by students on the behaviour and delivery of tutors was noteworthy. They highlighted the level of enthusiasm, basic but essential pedagogical skills, the ability to demonstrate knowledge in a real life and authentic manner, reflecting Orlando's (2013) nine tenets of effective engagement in learning environments. These characteristics stress the importance of tutors being knowledgeable, professional, warm, accessible, enthusiastic, caring and being able to create a sense of community, safety and belonging. Students emphasised the significance of classroom communication as an essential pedagogical skill, additionally electronic communication and relationships beyond the curriculum were integral to their concerns. It behoves tutors to recognise that paying lip service to the worth of individual students demeans the profession, the learner and the learning experience.

The challenge for programme designers is the difficulty of adopting good practice within the constraints of large cohorts and high student: staff ratios. The challenge also extends to individual tutors in considering how they use assessment for learning. This suggests less reliance on traditional summative modes of assessment such as examination and essay writing and more use of imaginative, applied and user-friendly approaches that promote learning through assessment and feedback. This requires tutors to reflect on the efficacy of their practice from the student perspective rather than the traditions of their discipline.

Utilising different pedagogies is essential if experience is to match the expectations and needs of the modern student. In order to be effective learning and teaching organisations, universities must think beyond the traditional classroom context of learning. The onus is on every tutor to combine innovative/imaginative assessment with dynamic and relational experiences. If we are to provide a strong foundation for flexible, reflective and creative graduates, we must strive to transcend our own experiences, reticence and preferences if the profession is to adapt to the $21^{\text {st }}$ century.

\section{References}

Angrosino, M.V., \& Mays de Pérez, K.A. (2003). Rethinking Observation. From Method to Context. In N.K. Denzin \& Y.S. Lincoln, (Eds.), Collecting and Interpreting Qualitative Materials. London: Sage Publications, pp. 107-154.

Bain, J. (2010). Integrating student voice: assessment for empowerment. Practitioner Research in Higher Education 4(1):14-29. http://eprints.gold.ac.uk/4529/1/Integrating_student_voice-assessment_for_enpowerment.pdf 
Barnett, R. (2014). Conditions of Flexibility Securing a more responsive higher education system. Retrieved from https://www.heacademy.ac.uk/workstreams-research/research-and-policy/published-research

Beard, C., Clegg, S., \& Smith, K. (2007). Acknowledging the effective in higher education. British Education Research Journal, 33, 2, p 235 - 252. http://dx.doi.org/10.1080/01411920701208415 http://dx.doi.org/10.1080/01411920701208415

BERA (2011). Ethical Guidelines for Educational Research. British Educational Research Association. http://content.yudu.com/Library/A1t9gr/BERAEthicalGuideline/resources/index.htm?referrerUrl=http\%25253A $\% 25252 \mathrm{~F} \% 25252 \mathrm{Fwww} . y u d u . c o m \% 25252$ Fitem\%25252Fdetails\%25252F375952\%25252FBERA-Ethical-Gui delines-2011

Boud, D. (2007). Reframing assessment as if learning were important, in D. Boud and N. Falchikov (Eds.), Rethinking Assessment in Higher Education: Learning for the Longer Term. Abingdon: Routledge.

Bridges, P., Cooper, A., Evanson, P., Haines, C., Jenkins, D., Scurry, D., Woolf, H., \& Yorke, M. (2002). Coursework marks high, examinations marks low: discuss. Assessment and Evaluation in Higher Education, 8 (2): 154-169.

Buckley, C.A., Pitt, E., Norton, B., Owens, T. (2010). Students' approaches to study, conceptions of learning and judgements about the value of networked technologies. Active Learning in Higher Education 11(1): 55-65. http://dx.doi.org/10.1177/1469787409355875

Burke, V., Jones, I., \& Doherty, M. (2005). Analysing Student Perception of Transferable Skills Via Undergraduate Degree Programme. Active Learning in Higher Education, 6, 2, p 132-144. http://dx.doi.org/10.1177/1469787405054238

Byrne, M., Flood, B., \& Willis, P. (2002). Approaches to learning of European Business Students. Journal of Further and Higher Education 26(1): 19-28. http://dx.doi.org/10.1080/03098770120108275

Conway, M.A., Cohen, G., \& Stanhope, N. (1992). Why is it that university grades do not predict very long-term retention? Journal of Experimental Psychology: General 121 (3): 49-57. http://dx.doi.org/10.1037/0096-3445.121.3.382

Cooper, N.J. (2000). Facilitating learning from formative feedback in level 3 assessment. Assessment and Evaluation in Higher Education, 25(3): 279-291. http://dx.doi.org/10.1080/713611435

Creswell, J. W. (2007). Qualitative Inquiry and Research Design, Choosing Among Five Approaches. London, Sage.

Dutton, K., Hunter, P., \& Broad, C. (2012). Targeting induction and programme activities to manage student expectation and enhance engagement. In Andrews, J., Clark, R. \& Thomas, L. (Eds.), Compendium of effective practice in higher education retention and success. Aston University, Birmingham \& HEA, York.

Economic and Social Research Council. Teaching and Learning Research Programme [ESRC/TLRP]. (2009). Effective learning and teaching in higher education. Economic and Social Research Council. Teaching and Learning Research Programme.

Gibbs, G., \& Simpson, C. (2004). Conditions Under Which Assessment Supports Students' Learning. Learning and Teaching in Higher Education 1:3-31.

Gillham, B. (2000). The Research Interview. London: Continuum.

Gobo, G. (2004). Sampling, Representativeness and Generalizability. In C. Seale, G. Gobo, J.F. Gubrium \& D. Silverman (Eds.), Qualitative Research Practice. London: Sage. http://dx.doi.org/10.4135/9781848608191.d34

Habeshaw, S., Gibbs, G., \& Habeshaw, T. (1993). 53 Interesting Ways to Assess your Students, 3rd ed. Bristol: Technical and Educational Services.

Hativa, N., \& Birenbaum, M. (2000). Who Prefers What? Disciplinary Differences in Students' Preferred Approaches to Teaching and Learning Styles. Research in Higher Education 41(2), 209-236. http://dx.doi.org/10.1023/A:1007095205308

Hattie, J.A. (1987). Identifying the salient facets of a model of student learning: a synthesis of meta-analyses. International Journal of Educational Research, 11, 187-212.

Hiemstra, R., \& Sisco, B. (1990). Individualizing instruction. San Francisco: Jossey-Bass.

Hockings, C. (2009). Reaching the students that student-centred learning cannot reach. British Education Research Journal, 35, 1, p 83 - 98. http://dx.doi.org/10.1080/01411920802041640 
Hounsell, D. (1987). Essay writing and the quality of feedback In J.T.E. Richardson, M.W. Eysenck \& D. Warren-Piper (Eds.), Student Learning: research in education and cognitive psychology. Milton Keynes: Open University Press and Society For Research into Higher Education.

Jenkins, A., Breen, R., Lindsay, R., \& Brew, A. (2003). Reshaping teaching in Higher Education: Linking Teaching with Research. Sterlying, VA \& London: Logan Press.

Jones, A. (2009). Generic attributes as espoused theory: the importance of context. Higher Education. 58, 175-191. http://dx.doi.org/10.1007/s10734-008-9189-2

Kandiko, C.B., \& Mawer, M. (2013). Student Expectations and Perceptions of Higher Education. London: QAA.

Kane, R., Sandretto, S., \& Heath, C. (2002). Telling half the story: A critical review of research on the teaching beliefs and practices of university academics. Review of Educational Research. 72(2), 177-228. http://dx.doi.org/10.3102/00346543072002177

Kniveton, B.H. (1996). A Correlational Analysis of Multiple-Choice and Essay Assessment. Research in Education, 56.

Linnenbrink, E.A., \& Pentrich, P.R. (2003). The role of self-efficacy beliefs in student engagement and learning in the classroom. Reading and Writing Quaterly, 19, 119-137. http://dx.doi.org/10.1080/10573560308223

Marshall, C., \& Rossman G.M. (1999). Designing Qualitative Research (3rd ed). Thousand Oaks Ca: Sage.

McInnis, C. (2001). Signs of disengagement? The changing undergraduate experience in Australian universities. University of Melbourne. Centre for the study of Higher Education.

Morss, K., \& Murray, R. (2005). Teaching at University. London: Sage.

Moustakas, C. (1994). Phenomenological Research Methods. Thousand Oaks, CA: Sage.

National Union of Students. (2008). NUS Student Experience Report. London: NUS.

Ning, H.K., \& Downing, K. (2012). Influence of student learning experience on academic performance: the mediator and moderator effects of self-regulation and motivation. British Education Research Journal, 38, 2, 219 - 238. http://dx.doi.org/10.1080/01411926.2010.538468

Orlando, M. (2013). Nine Characteristics of a Great Teacher. Higher education teaching strategies from Magna publications.

Retrieved

from http://www.facultyfocus.com/articles/philosophy-of-teaching/nine-characteristics-of-a-great-teacher.

Penny, A.J., \& Grover, C. (1996). An analysis of student grade expectations and marker consistency. Assessment and Evaluation in Higher Education, 21(2), 173-184. http://dx.doi.org/10.1080/0260293960210206

Pollard, A. with Anderson, J., Maddock, M., Swaffield, S., Warin, J., \& Warwick, P. (2008). Reflective Teaching, (3rd ed). Evidence-informed Professional Practice. London: Continuum.

Poland, B.D. (2002). Transcription Quality. In J.F. Gubrium \& J.A. Holstein, (Eds.), Handbook of Interview Research: Context and Method (pp. 629-649). London: Sage Publications.

QAA. (2011). Understanding assessment: its role in safeguarding academic standards and quality in higher education. London: QAA.

Railton, D., \& Watson, P. (2005). Teaching Autonomy 'Reading Group' and the Development of Autonomous Learning Practices. Active Learning in Higher Education, 6(3), 182-193. http://dx.doi.org/10.1177/1469787405057665

Remedios, R., \& Lieberman, D.A. (2008). I like your course because you taught me well: the influence of grades, workload, expectations and goals of students' evaluations of teaching. British Education Research Journal, 34, (1), 91-115. http://dx.doi.org/10.1080/01411920701492043

Richardson, J.T.E. (2003). Approaches to studying and perceptions of academic quality ensure web-based course. British Journal of Educational Technology, 34(4), 433-442. http://dx.doi.org/10.1111/1467-8535.00340

Reischmann, J. (2004). Andragogy. History, Meaning, Context, Function. Retrieved 12 September 2013, from http://www.andragogy.net.

Ritchie, J., \& Lewis, J. (2012). Qualitative Research Practice. London: Sage.

Scouler, K. (1998). The influence of assessment method on students' learning approaches: multiple choice question examination vs essay assignment. Higher Education, 35, 453-472. http://dx.doi.org/10.1023/A:1003196224280 
Seale, J. (2010). Doing student voice work in higher education: an exploration of the value of participatory methods. British Education Research Journal, 36(6), 995 - 1015. http://dx.doi.org/10.1080/01411920903342038

Silverman, D. (2000). Doing Qualitative Research: A Practical Handbook. London: Sage.

Struyven, K., Dochy, F., \& Janssens, S. (2005). Students' perceptions about evaluation and assessment in higher education. Assessment \& Evaluation in Higher Education, 30(4), 331-347. http://dx.doi.org/10.1080/02602930500099102

Synder, B.R. (1971). The Hidden Curriculum. Cambridge, MA: MIT Press.

Thomas, L. (2012). Building student engagement and belonging in Higher Education at a time of change: final report from the What Works? Student Retention \& Success programme. Paul Hamlyn/Hefce/Hea.

Van Den Hurk, M. (2011). The relation between self-regulated strategies and individual study time, prepared participation and achievement in problem based curriculum. Active Learning in Higher Education 7(2), 155-169. http://dx.doi.org/10.1177/1469787406064752

Wotjas, O. (1998, September 25). Feedback? No, just give us the answers. Times Higher Education Supplement. Retreived from http://www.timeshighereducation.co.uk/109162.article

Yorke, M., Bridges, P., \& Woolf, H. (2000). Mark distributions and marking practices in UK higher education: some challenging issues. Active Learning in Higher Education, 1(1), 7-27. http://dx.doi.org/10.1177/1469787400001001002

Zembylas, M., \& McGlynn, C. (2012). Discomfiting pedagogies: emotional tensions, ethical dilemmas and transformative possibilities. British Education Research Journal, 38(1), 41-59. http://dx.doi.org/10.1080/01411926.2010.523779 